Portland State University

PDXScholar

$11-7-1997$

\title{
The Influence of Cathar Philosophy, Thought and Everyday Life on the Works of Selected Troubadour Poets
}

Marilyn Ann Lucas

Portland State University

Follow this and additional works at: https://pdxscholar.library.pdx.edu/open_access_etds

Part of the French and Francophone Language and Literature Commons Let us know how access to this document benefits you.

\section{Recommended Citation}

Lucas, Marilyn Ann, "The Influence of Cathar Philosophy, Thought and Everyday Life on the Works of Selected Troubadour Poets" (1997). Dissertations and Theses. Paper 5321.

https://doi.org/10.15760/etd.7194

This Thesis is brought to you for free and open access. It has been accepted for inclusion in Dissertations and Theses by an authorized administrator of PDXScholar. Please contact us if we can make this document more accessible: pdxscholar@pdx.edu. 


\section{THESIS APPROVAL}

The abstract and thesis of Marilyn Ann Lucas for the Master of Arts in French were presented November 7, 1997 and accepted by the thesis commitee and the department.

COMMITTEE APPROVALS:

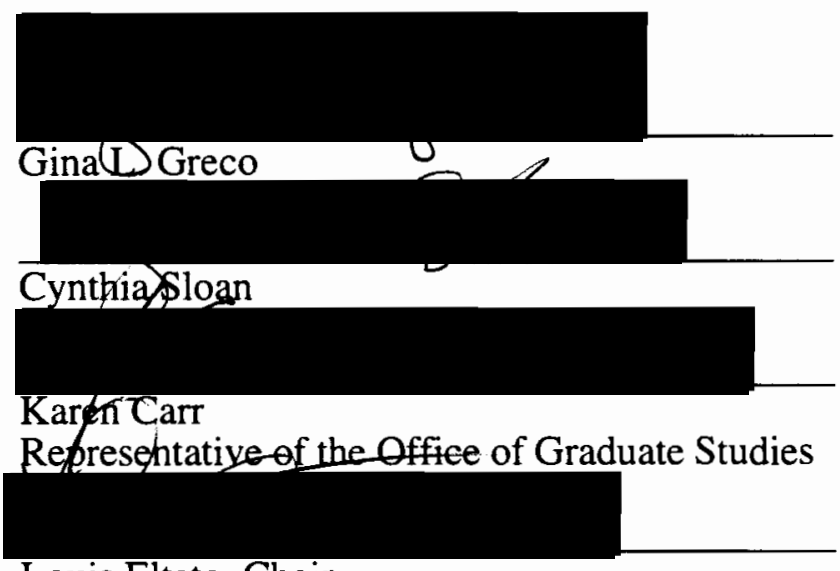

DEPARTMENT APPROVAL:

Louis Elteto, Chair

Department of Foreign Languages and Literatures

$* * * * * * * * * * * * * * * * * * * * * * * * * * * * * * * * * * * * * * * * * * * * * * * * * * * * * * * * * * * * * * * * * * * * *$

ACCEPTED FOR PORTLAND STATE UNIVERSITY BY THE LIBRARY

by

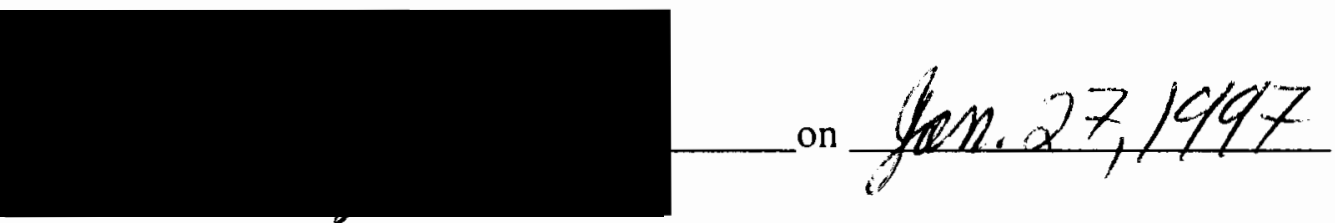




\begin{abstract}
An abstract of the thesis of Marilyn Ann Lucas for the Master of Arts in French presented November 7,1997.
\end{abstract}

Title: The Influence of Cathar Philosophy, Thought and Everyday Life on the Works of Selected Troubadour Poets.

This thesis presents an examination of the influence of Cathar philosophy, doctrine, and life style on selected works of troubadour poets. Whether Cathar ideology is revealed clearly, secretly, allegorically, symbolically, or not at all in the poetry of the troubadours, has been discussed and debated from a variety of angles by various scholars. There appears to be no completely convincing evidence either way. Some authors argue that the language of the troubadours was in fact the secret language of the Cathars. Others contend that the troubadours and the Cathars had very little to do with each other. Denis de Rougemont takes a more moderate position, arguing that the troubadours and the Cathars cannot be understood separately, considering they existed in the same place and time in history: specifically in Occitania from about 1150 to 1270 .

In this thesis I will attempt to draw comparisons and demonstrate links and similarities between the thought, doctrine and life style of the Cathars and the themes, images, and allusions in selected troubadour poetry. Several themes and ideologies which are intrinsic in Cathar belief seem not to be in conflict with symbols and themes in troubadour poetry. I will provide textual analysis of a variety of chosen poems by selected Provençal poets. 
The introduction and the chapter on Cathars in Languedoc offer historical information regarding the origins, geographical locations, social order, beliefs, doctrine, and everyday life of the Cathars. The chapter on the troubadours provides historical contexts as well as an explanation of the corpus and genres of their works.

This thesis will attempt to link common themes found in the texts of the troubadour poetry to the ideas prevalent in Cathar belief. The themes of anti-clericalism, Love, and mysticism are outlined and explored. Disdain for and rejection of the Church of Rome coupled with strong sentiments of anti-clericalism are themes found in the works of the troubadours as well as in Cathar thinking. Concerning the attitude of Love, there was an imbedded bond between cortezia and the religious atmosphere among the Cathars. Mysticism, a quest for the ideal, provided a spiritualized and symbolic expression of love, ideas which are present in both the mystical theology of the Cathars and the language of the troubadours.

Peire Cardenal and Guilhem Figuira demonstrate a moral and political outrage in the form of satirical and often violent but eloquent poetry directed at the clergy and the invading French from the North. Jaufré Rudel, whose language is less complicated, seems to derive his ideas about perfection and divine love from mystical themes common to Cathar theology. Dame Carenza, Alaïs and Iselda show evidence of gnostic allusions, while providing a mixture of colloquial and religious language. 


\section{THE INFLUENCE OF CATHAR PHILOSOPHY, THOUGHT AND EVERYDAY}

\section{LIFE ON THE WORKS OF SELECTED TROUBADOUR POETS}

by

MARILYN ANN LUCAS

A thesis submitted in partial fulfillment of the

requirements for the degree of

\section{MASTER OF ARTS}

in

FRENCH

Portland State University

1997 
For love is no sin, but a virtue that makes the bad good, and the good better.

Now Joy and Courtesy offend the great

So wicked have they grown.

Guilhem Montanhagol 


\section{TABLE OF CONTENTS}

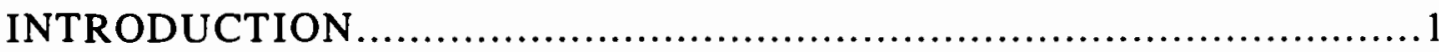

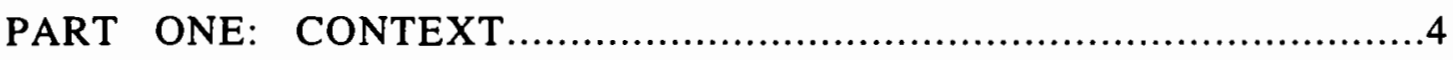

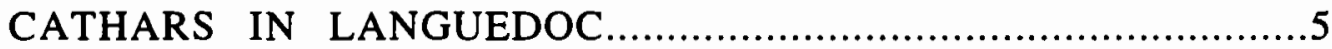

THE TROUBADOURS ...................................................

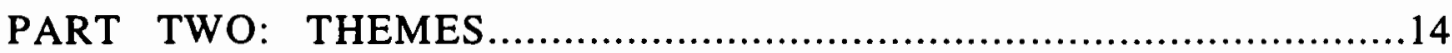

ANTI-CLERICALISM............................................... 15

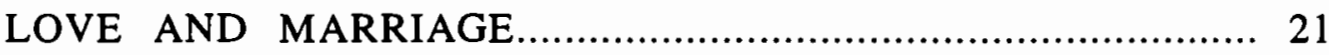

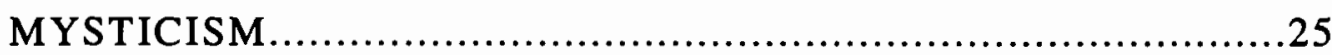



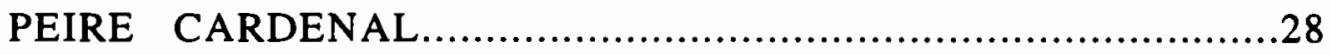

OTHER SELECTED POETS: GUILHEM FIGUEIRA, JAUFRE RUDEL AND DAME CARENZA, ALAIS AND ISELDA .................................44

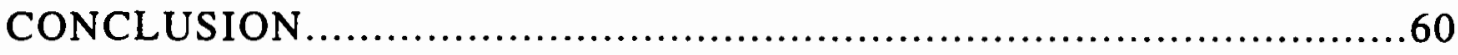

WORKS CONSULTED ....................................................... 71 


\section{INTRODUCTION}

Certain aspects of contemporary Western civilization had their

origins in Central and Southern France at a unique time in history. The Middle Ages, which has often been regarded as a static period, hostile to the pursuit of knowledge and unconcerned with the beauty of nature and the nature of love, is no longer viewed so narrowly. In the varied and extensive territory known as Occitania in Southern France, an area from Bordeaux on the Atlantic to Grenoble in the Alps and down to the Pyrenees, a gracious life style developed during the medieval period which created the brilliant courts of Poitou, Toulouse and Provence. This society showed a greater freedom and mobility than that of northern France and favored diversity rather than conformity. As opposed to the male dominated feudal society in the North, women in the South enjoyed comparative freedom and respect.

For example, in the intellectual realm, the poetry and song of the troubadours marked an era of the emancipation of women, and consequently of human beings generally. The openess and tolerance of Provençal society made for a receptive and fecund arena for intellectual and spiritual movements. These regions were regarded by the Church to be dangerous breeding grounds for heretics and the Cathars, or Albigensians, some of whose leaders were women, made thousands of converts, including many nobles. This pluralistic culture was violently suppressed in the thirteenth 
century by the Crusades against the Cathars and the forces of the Inquisition. Although this dynamic culture may have been seriously threatened, it did not completely die out, and its influence, I believe, is stronger than most give it credit. In the period of crisis, generally considered to be $1209-1244$, the troubadours were not silent, and there were as many songs of protest as of love (Marks, 12).

A variety of poets and singers, both men and women, some noble, some of humble origins, revived the language of lyric poetry and created an ideal of gallantry, sincerity, and joyousness which has influenced our idea of the "pursuit of happiness." The work of these artist seems to reveal a desire to alter societal structures both at the personal level (love, courtliness) and the political level (anti-clericalism, anti-Northern sentiment). Concurrently, the tenth and eleventh centuries marked a period when Christians were not satisfied with the traditional responses from the Church concerning widespread poverty which stood in stark contrast with the wealth and power of the Church. The stance of the Catholic clergy no longer matched the idealized image of a simple and basic church that was evangelical and pure. As a result, groups of the faithful set about to find answers to their questions. In 1163, Eckbert of Schonau, canon of Cologne cathedral, called these dissenters "Cathars," from the Greek katharos, meaning pure. The term "Albigensian" undoubtedly comes from St. Bernard's mission to Albi in 1163 . It was the beginning of the movement to eradicate a threat to the power and control that had belonged to the Church in Rome. 
The Church made its arguments for the elimination of the Cathars behind a veil of erudite excuses (Neil, 7). Historians obviously Catholic have not investigated with a sense of tolerance which would allow them to admit that Catharism was a legitimate religion. The Albigensian Crusade or war against the Cathars lasted 45 years. One million people were victims. Its effect was two fold: first it eliminated Catharism, thus reinforcing the Church's power and unity; and secondly, France was united as one country, eracing the importance and independence of the South of France (Neil, 7). The violence by the North has been explained away with intellectual reasoning depicting Catharism as a doctrine, not a religion. At this same time the troubadours were silenced. Their ideas of love and their criticism of the clergy and the invasive French from the North were thought too dissident for the Church to tolerate. These two movements, symbolic of creative, diverse, and innovative thought, were supressed, ending an era that has remained intriguing, mysterious, and influential to this day.

Whether Cathar thought and ideology is revealed directly, secretly, allegorically, symbolically, or not at all in the poetry of the troubadours who, coincidentally, shared the same space and time in history (Occitania,1150 to 1250), has been discussed and debated from a variety of angles by various scholars. The theses run the gamit from extreme to temperate. Otto Rahn, for example, claims that the language of the troubadours was in fact the secret language of the Cathars. Henri-Irenée Marou dismisses this argument as completely "farfelu." He contends that the troubadours and 
the Cathars had very little to do with each other, and certainly that Cathar traces would not be found in troubadour songs. Others, namely Péladon and Eugene Aroux, together with Rahn have proposed that the romances of Chrétien de Troyes were written as secret chronicles of the Cathar Church. Denis de Rougemont takes a more moderate position, citing origins and giving illuminating insights into possible influences in certain works, contending that the troubadours and the Cathars cannot be understood separately. In this thesis I will attempt to establish my argument somewhere in the middle, providing links, comparisons, and similarities between the thought, doctrine and lifestyle of the Cathars and the themes, images, and allusions in selected troubadour poetry. I will demonstrate how these themes are mirrored, although often ambiguously, in the works. I will offer textual analysis of a variety of chosen poems by Peire Cardenal, Guilhem Figueira, Jaufré Rudel, and Dame Carenza, Alaïs, and Iselda. 
PART ONE:

CONTEXT 


\section{CATHARS IN LANGUEDOC}

Although there were many previous heresies (later I will identify and define this term in relation to the spiritual climate of the Middle Ages) in the eleventh and 12th centuries a trend known as the religion of Catharism, a word derived from Greek, katharis, meaning "pure," spread rapidly. The original group of Cathari, known as Bogomils, had been formed in Bulgaria and the Balkans in the tenth century. They based their beliefs on the doctrine of Manichaeism. In this thought, there was a perpetual dualism between God, represented by light and spiritual enlightenment, and the world of Satan, symbolized by darkness and all material things. Man was composed of matter, which belonged to Satan, but Christ, the ideal light soul, could redeem from each human the part of light given by God.

Much of the Cathars' creed and ritual remains obscure because of their need for secrecy. They are known to have renounced all violence, homicide (suicide was accepted), war, and secular justice. Any form of lying or evasion of the truth was rejected. Marriage was not a sacrament, nor was it sanctioned. The Cathars rejected all outward symbols of Catholicism including the entire hierarchy of the Church and the Pope. They considered the Church of Rome to have lost the ideals of simplicity. They retreated in many aspects to the ideals of early Christianity. Both men and women could be parfaits (perfecti/perfectae; male/female perfects), a name given by their followers to 
those who preached the faith.

The Cathar "bishops" and "deacons" were men. The parfaits were ascetics who practiced surrender of the flesh to the spirit as a means of perfection. Had it not been for the two classes, the religion probably would have failed. But the believers (croyants or credens/credentes) were not bound by strict rules. The parfaits were ordained by receiving the Cathars' one and only sacrament, the consolamentum, a "laying on of hands" together with a "kiss of peace." The croyants usually received the consolamentum only when death was imminent.The sacrament could be administered by either a man or a woman. Until that moment the believers were able to love as they wanted.The parfaits were never authoritarian in forcing their ways of life on others, but once the dying person had received the consolamentum, his or her time on earth had to be spent as a Perfect (Nelli, 238).

The Cathars embraced a very rigorous, dualistic explanation of God and the Cosmos. For the Cathars, God in fact thought, and from these thoughts a Spirit was born. From this Spirit, there came two major principles: those of Good and Evil. The Cathar dogma and philosophy implies that Man has the power to orient himself toward one of these ways or paths. Through his journey, Man will acquire interior or inner freedom. Evil is therefore necessary to Man so that, through trial and error, he will reach this this inner freedom and the reasoning that accompanies it.

The goal of the human mission is to recognize the Evil in oneself, try to resolve 
it, and transform it into Good. To assure this transformation, Man has at his disposal two weapons: purity and Love (disinterested, detached love). The object of this Love includes more than fellow humans, but rather all of human creation: animals, vegetation, minerals and the cosmos.

According to Cathar doctrine, in the beginning, all creation was Spirit. After a long descent through the course of time, Matter was formed, which is the opposite of the Spirit, and impregnated the Spirit. The human mission is therefore to deliver the Spirit which is imprisoned in Matter (Julien, 4). There are thirty steps, called Eons, where the Spirit falls into Matter (or the material world). Creation is passed through the state of heat, then light, air, and water of the actual material world. There are spiritual beings which exist in each level or stage, and the 29th Eon is where Sophia dwells, the Divine Wisdom, which the Cathars called "La Dame de Lumière" or "La Vierge de Lumière." Man must force himself to attain this Divine Wisdom. To unite with Sophia and to bring spirituality to the material world are the goals for the human mission. According to Cathar thinking, this end may be realized by a slow ascent toward perfection whereby Man can become again the spiritual being he once was.

Medieval literature, often inspired by gnostic or Manichean ideas, seems to translate this aspiration of the human soul toward achieving light. This literature, especially the words and ways of the troubadours, brought a radical burst of original thought and art with the notion of joy d' amor (Julien, 7). The troubadours wanted to establish "le contact entre l'individu raisonnable et l'intelligence, agente, par laquelle l'homme se relie au monde divin" (Nelli, La Vie Quotidienne des Cathares du Languedoc au XIII siècle 27). 
Peter Biller notes that although Catharism was theologically considered a "heresy" to the Catholic Church, it was not structurally and socially a sect, but a Church (Biller, 62). It was not born of the Catholic Church as Waldensianism was.

Ecclesiastically it was autonomous and highly organized. It had its own clergy, heirarchy, its diocesan boundaries, and its formal meetings called general councils or general chapters (Biller, 62). Catharism had great strength throughout Languedoc. Women often took part in elections to the municipal government, or "communes." Many of the city leaders were Cathars.

The Cathars and troubadour poetry were both casualties of the Albigensian (or Cathar) Crusade. Within fifty years of Pope Innocent's call to arms, the great cities of the south lay in ruins. Béziers, Carcassonne, Narbonne, Toulouse --- all were overrun. After the Fall of Montségur (considered to be the last stronghold of Catharism) in 1244, forced marriages between Occitanian women and northern lords established French control of the South. Women no longer had rights that they had enjoyed under Occitanian law. Primogeniture was enforced. French, rather than Provençal, became the language of official use.

All Cathars at some point were obliged to live hidden. It is not suprising that information concering them is scarce. Repression became so intense that one had to choose between exile and the renouncement of one's faith in order to survive (Muller, 2). By the end of the thirteenth century there were very few Cathars left in Languedoc 
and the South. The atmosphere of repression which, like the Crusades against the Albigensians, was as much political as religious in nature, destroyed not only diversity of opinion, but also all that had made the rich and beautiful Provençal civilization possible. Likewise, the troubadours were in many cases reduced to the status of faidits, dispossessed persons, and many of their patrons were either dead or in exile. The troubadours diminished in number, and the quality of their poetry, deprived of its true substance, declined. 


\section{THE TROUBADOURS}

There were more than 460 known troubadours, otherwise called poets of langue $d^{\prime} o c$. They belonged to all social levels and came from all regions in Occitania. The oldest of these poets are those of the Midi ("les trobadores") from Provence. Their name is derived from low Latin tropare, which is trobar in Provençal and which means "composer of tropes " or musical airs before taking on the general meaning "to invent." The same verb in the dialect of langue d'oil is "trouver" or "to find." We derive therefore "troubadours" in the south and "trouvères" in the north. I will focus on the works of the poets in the south of France since this is the region of the Cathars and thus their influence on and correlation to the troubadours.

The troubadours sang for the most part about women and lovers, but their œuvre is not lacking in political or clerical commentary. They were led to define life as an integral part of courtly love. Love was the most important of all virtues. But this poetry is also known to have magnified unhappy love. Denis de Rougemont remarks:

The cultivation of passionate love began in Europe as a reaction to Christianity (and in particular to its doctrine of marriage) by people whose spirit, whether naturally or by inheritance, was still pagan. It is in the middle of the twelfth century that love was first recognized and encouraged as a passion worth cultivating. Passionate love was then given a name that has become familiar. It was called cortezia, or courtly love. The 
troubadours' ideal of love, with its combination of physical desire and chastity, a sublimated love in which the moment of consumation was constantly deferred, may seem unbearably unrealistic today, but it is what is called in French l'attente amoureuselove's expectant waiting- the eager anticipation. It was the expression of a very real condition that was unacknowledged until then and which greatly enriched the language of the emotions, especially in France (Marks, 180).

In southern France in the twelfth century there was a heightend interest in knightly culture coupled with the appearance of the troubadours. From the twelfth to the thirteenth century, feudalism, the spirit of chivalry, and religious fervor were the dominant traits of French civilization (Poésie Lyrique au Moyen Age, 5). To serve one's lord, to serve one's lady, to serve God: this triple ideal was manifested in all works of art during the period. The stress on courtly chivalry tended to promote religious tolerance, such as that shown toward the Cathars, rather than religious fanaticism.

Before developing further my discussion of the relationship between troubadour poetry and Catharism, I will briefly outline the fundamental themes and genres of troubadour poetry, beginning with love, the fundamental poetic theme of the troubadour corpus. Attached to love are the themes of the charm of nature, the rebirth of springtime, the blooming of flowers, and the song of birds. These themes and their related imagery led ultimately to the larger religious theme that through nature, one discovers the Creator. 
The realities which opposed love also appeared in troubadour lyrics. "Le jaloux," the suspicious husband who tries to separate the lady from all that would make her life bearable, are frequent obstacles to love. Intrigues often involving a third person are characterized, including an "accomplice" who makes the vigil so that the "coupables" will not be surprised. Out of this scenario comes the genre of the "chanson de l'aube" in which the lovers lament the approaching dawn and their imminent separation.

The troubadours talk not about Love of frivolous and cruel games, but instead about mutual feelings between partners; "égaux et libres." It is a love void of jealousy and pride. It avoids avarice and cupidity. These social concepts were readily found in the culture of Occitania which was filled with Catharism. Joy d'Amor, joy and a game at the same time, was a real exercise in perfection. "Melhorar," the langue d'oc word for améliorer, to make better, is an integral part of the joy of love which involves the whole person, in the way he leads his life, and in the sense of responsibility that each one displays.

Some troubadours-- such as Jaufré Rudel, Bernard de Ventadour, Raimon de Miraval, Marcabru, and Pierre d'Alvernaha-- sang about the active force of nature, the heart, the soul, the free human spirit, and the secrets of hope and renewal. They especially exhalted Love. Guillaume de Poitier talked mainly of sensual love; Marcabru wanted "un amour pur et parfait; and Peire Cardenal hoped to "purifie son cœur des 
mauvais désirs", criticizing the man "qui place mal son Amour, et qui néglige ce qu'on devrait aimer" (Julien, 7).

There were "courts of love" of which Eleanor of Aquitaine was a great model together with her daughter Marie. The Courts of Love were a kind of arbitrating body which treated the delicate matters of fin' amor and in general re-evaluated the entire relationship of men and women (Marks, 180). The decisions (or actually social laws) were passed independently by women on issues directly concerning them. This was a challenge not only to the whole authoritarian structure of the old-fashioned feudal system, but also to the inferior role accorded by the Church to all women. The fact that some women in these gatherings had political power of their own made their ideas seem all the more "subversive" to the supporters of the feudal authority (Marks, 182). Some writers have supposed that Eleanor was in fact a Cathar, but no proof of that exists.

History represents the second fundamental theme of the troubadour corpus. The troubadours and trouvères lived in the time of the Crusades. Some poets were inspired to write "des chansons de croisade" and funeral orations or planhs, which eulogized illustrious persons who had died. The sirventes, made allusions to the battles, both moral and in actual war, which bloodied the South of France during the crusades against "les albigeois" or the Cathars.

The troubadours created their works in many literary genres, la chanson being 
the most often used-- a kind of ode consecrated to passion. The other genres include l'aube in which the lovers rail against that which wakes them, complaining that the night was too brief; le planh, a complaint on the death of a missed person, celebrating either an illustrious person on the social level or a loved one on the personal level; la tenson, a dialogue in which one of the interlocutors must defend the opposite opinion of the other person's proposal; and le sirventes which offers moral, religious, or political satire.

Troubadour poetry is often written very obscurely, so that the message is ambiguous. It is in the language, although most difficult to understand and analyze, that I will attempt to illustrate connections and some kind of relationship between selected troubadour poets and Cathar thought. This thesis will attempt to present an examination of Cathar philosophy, doctrine, and everyday life and some of its influences and similarities in troubadour writings.

The principle theme that unites all troubadour poetry- whether devoted to love, history or politics - can be assumed in one word which had a universal meaning in that era: paratge, which means honor, "droiture," equality, negation of the right of the strongest, and respect for the human being, for oneself and that of others (Neil, 7). Le paratge was applied in all domains: political, religious, and sentimental. It addressed not just one category of people but rather all levels, whatever their condition and their ideas. Troubadour poetry was not about a purely local movement, destined for a people speaking precisely the same language, but it was a humanist literature in the largest 
sense of the term (Niel, 6).

While love is the predominent theme of their corpus, I will show that the message of the troubadours was much more than declarations of love: "Leurs poésies sont le reflet d'un état" (Niel, 7). This era seems to have promoted or to have reflected a need for expressions of repressed or unpopular sentiments. The Church was strict in its dogmas and applications of love. Women were to be feared and placed in a second class positon. The fact that women in the South of France had exhalted positions of social and political power went against the basic premises of the Church in Rome. Two similar movements came about to express this need for change. The rise of the Cathar religion and the troubadour movement, which was the vehicle of an anti-comformist way of seeing the world, simutaneously developed. It was in this atmosphere of growing dissent, that many troubadour poets began to write words of criticism, satire, and moral outrage. 
PART TWO:

THEMES 


\section{ANTI- CLERICALISM}

For the sake of a wider understanding of the sentiments and general atmosphere in the South at this period it is necessary to explore the situation of the Church, since it was regarded as an ever imposing power. The Catholic Church had become, by the time the Albigensian Crusade was under way, a rigid authority, imposing its religion by force. The aristocracy of the Midi was openly contemptuous of the clergy and likewise the clergy did not relent in its criticism of the nobilty in the South. This power struggle led to a war. Many nobles respected the integrity of the Cathars and felt they were entitled to the same protection as other subjects. To the vast majority of the nobility, the idea of a war in the name of religion was deplorable.

The Church had gradually become rich over centuries of receiving gifts, bequests, and imposing huge dues and taxes on an already impoverished people. It administered immense domains. It had become to a large extent secularized, possessing an army to insure its collection of dues.

In rising dissent against the orthodox church, the Cathars held high ideals concerning the value and dignity of life. They saw around them an institution (the established Church) that practiced usury, rapine, and debauchery. In their philosophy of dualism, God was seen as all good, therefore they did not believe that the God of the 
Old Testament could be a righteous God. In distinction, to Catholics, the destruction and punishment of evil doers did not seem to be a problem. Cathar morality was more subtle and demanding. The Cathars, following the Gospels, condemned the death penalty and other punuitive actions believing that a kind of rehabilitation would make people better citizens.

The nobility and the common people criticized the Church for its excessive wealth, which was out of proportion for the services it provided. There was a widespread mistrust and hatred in Languedoc of the Catholic Church, and Catharism provoked and revealed this (Oldenbourg, 72). The movement found a sympathetic ear at every level of society. The troubadours were no exception.

Zoë Oldenbourg sums up the situation in these words:

In a Catholic country, where a large proportion of property, wealth, and public authority was in the hands of the Church, and where moreover the Church had control and sanction over every act in people's lives, whether public or private, the population as a whole were either indifferent or actively hostile towards Catholicism. A new Church had been established [Cathar], and had won general approval and regard. It was already a part of the country's national life, and continued to gain ground without recourse to civil strife or spectacular public riots. Its avowed aim was the destruction of the established Catholic Church, which constituted the one target against which this half- 
popular, half-mystical movement directed its hostile energies. Thus Catholicism slowly began to lose all contact with the country's deeper spirtual needs; by progressive self-identification with a specific social caste, concerned above all else to defend its own interests, the Church became increasingly isolated from reality. (Oldenbourg, 34)

On the eve of those events which brought upon Languedoc the catastrophe that was to cost her independence, the Church stood neither for justice, order, peace, charity, nor God; what she represented was the Papacy. The genuinely tragic position in which she found herself led her into a most terrifying confusion of values, and made her subordinate all moral considerations to the defense of her temporal interests (Oldenbourg, 75).

The Cathars refused to accept temporal power. For the Cathars, the Roman Church was the "Church of the Devil" since it had used the "arm of the evil" by imposing suffering and death to good Christians.

This then was the landscape which the troubadours brought to verse, and in the specific form of the sirventes, a vehicle to vent the hatred, rage, and disappointment of the majority of the population of Languedoc. The particular heresy of the Cathars was in their dedication to obey God only and not the Church of Rome. The formation of the underlying thesis for their condemnation of the Church was: since the prelates of the 
Church were corrupt, they could not therefore be vehicles of Grace. The Cathars rejected the principle of the priesthood, as well as the sacraments, including baptism and the eucharist (Oldenbourg, 36).

René Nelli, Cathar specialist, actually describes this historical conflict as a moral crisis (Nelli, 45). The thinking of the Cathars was juxtaposed with the philosophy of the existing bourgeois and feudal society. Catharism served as a general movement of evangelical renovation in Languedoc, while the Church of Rome was considered the work of the devil. Catharism was at the core of the growing fundamental antagonisms of the era.

The important Occitanian lords did not feel that Catharism was threatening the feudal society. René Nelli cites circumstances proving that Catharism was in keeping with the spirit of the South. Likewise, Catharism seemed to side with the anticlericalism of the "guerriers" of the South in their moral rebellion against the Church. In fact this proved to be a favorable climate for spreading the Cathar word. The "guerriers" had a reputation for enjoying the good life and were not interested in adhering to the dictates of Rome (Nelli, 23). In addition, they did not take the institution of marriage required by the church very seriously. In general their spirit of independence contrasted starkly with the requirements of the Church. The secular South as a whole was just as interested in ridding themselves of the yoke of Rome as were the Cathars.

Contrary to some thinking, Nelli contends that Catharism was never interested in 
dissolving the family. In fact they found in the peasant families a climate of purity which could not be found to the same degree in noble or bourgeois families.

I will make some comments about peasant life because they influenced and were influenced by the poet Peire Cardenal. From an earlier disdain of the peasants, seeing them as simple-minded folk who only knew how to work the field, he wrote:

Ce sont des déplaceurs des bornes malhonnête/ Ils déclarent faussement les terres à cens.

Catholics, and even Peire Cardenal whom Nelli refers to as a "chrétian reformiste," were outraged to see the peasants working on Sunday and feast days. However, in the latter part of the thirteenth century, peasants became more instructed and their lives included somewhat more leisure time (Nelli, 45). This change was noted by Peire Cardenal:

Les vilains qui n'avaient pas coutume d'avoir du sens, sauf pour travailler la terre, sont aujourd'hui devenues habiles, savants, et déturés, avant de s'engager par serment, ils réclament un contract. (Nelli, Vie Quotidienne, 134)

Here Cardenal, by writing these lines, is in effect calling the peasants to arms or to consciousness by reminding them to defend their rights and not be duped and cheated by the Church. After having been obliged to pay indentures, taxes, and being obliged to forced labor, the additional burden of paying tithes was seen as intolerable (134). It was the tithes (dimes) which provoked the exasperation of the peasants. They were even 
asked to pay tithes on their animals! Many people were excommunicated for refusing to pay the tithes. This outraged the people and later was expressed in these terms:

You will never see anywhere in the Scriptures that God excommunicated anyone. It is the clergy who invented this idea to better dominate the people.

Gradually, many people were prevented from entering their churches. The church doors were closed because they had not paid their taxes or tithings. They were outsiders:

Nous faisons les églises ... nous achetons tout ce qu'il faut pour les orner. Les églises sont à nous, et l'on nous chasse! (135).

Cathars were not the only ones promoting this theme. Many people longed for a simple and pure means of expressing their faith. They considered themselves abused, and longed for someone to protect them against the clergy (136).

By this time Peire Cardenal was extensively read throughout the county of Foix. He was the first to compare the Inquisitors to wolves (lobasses). He wrote prolific satiral poems directed against the invading French from the North and the clergy. In this way he was able to speak for the people. He criticized the clergy in the following sirventes:

Si tu excommunies à tortil s'adresse à l'évêque je crois que tu te punis toi-même.

Il ne convient pas que tu contraignes tes gens, sauf dans la mesure où la raison le permet (mas tan com razon consen). 
Et ailleurs: Toi qui établis contributions forcées (toltas) et tailles, et qui ruines et tourmentes ton peuple,

ne penses- tu pas que tu sois dans le péché? (145)

René Nelli contends that Cardenal feels a certain responsibility to instruct and direct this outrage of the people. He is essentially leading them toward an "esprit critique." He states that they were driven to find a means of expressing their disgust, and found it in the new religion:

On est frappé de la netteté avec laquelle les paysans prennent conscience, vers 1300 , du caractère injuste des charges qui pèsent sur eux. Le Catharisme est l'expression de leur révolte. (137)

We will find then in the satires and critiques of Peire Cardenal, Figueira, Marcabru and others, that these poets were actually evangelists for a new way of directing the people's energy and faith. 


\section{LOVE AND MARRIAGE}

To the Cathars, the very state of being implied love; that is, everything that existed was defined not as "being" but as "love-being." Therefore, being without love suggested that one was in a state of "nihil" or "being without love." By means of the "consolamentum" one was able to reach this degree of "love-being." As I have mentioned, the Cathars advocated a return to the pure Christianity (pure love) of the early church. Concerning the attitude of love among the Cathars, it was the symbol of impossible union with women, since the flesh according to the doctrine was an instrument of the Devil. Likewise with the troubadours, love from afar (l'amour lonh) or distant love implied suffering. There was a divine element in love which allowed for divine flight or transcendence to the "other world." The Cathars alluded to the intoxication of the spirit. The Cathars were often referred to as the Church of Love. Ironically the "Church of Amor" was the opposite of the Church of "Roma" in orthographic terms as well as moral postures. Love was an integral part of living for the Cathars and it led to a virtuous and better life. Likewise said the troubadours: "L'amour n'est pas péché, mais vertu." The joi d'amor sung by the troubadours was more than a romantic concept of love-- it had been a way of life, an ideal of kindliness, brotherhood, and respect for the individual, the opposite of tyranny, arrogance, hypocrisy, greed and oppression. 
The Cathar idea of love as 'perpetually unsatisfied' found a parallel theme in troubadour poetry. In the span of twenty years a vision of women appeared that was not traditional. Woman was set above man, representing his nostalgic ideal. A poetry developed that treated this passion. I will argue that there is probably some historical cause for a link between the Cathar and troubadour phenomonen. Denis de Rougemont cites M. Jeanroy, a leading scholar on the subject: "If women were treated as lowly and dependant during the Middle Ages in the feudal institutions, where did the troubadours get their idea of love? It had to come from somewhere else" (de Rougemont, 77). Following the assumptions of E. Aroux and Péladan, de Rougemont contends that surely the mystery of this poetry has to be connected somehow to the cultural environment of the poets; not just the social but also the religious atmosphere must have determined the formal behavior and social usages of that environment (de Rougemont, 78).

I hope to show and reaffirm that Cathar thinking and the ideas of the troubadours were in some respects linked. Like de Rougemont, I think that courtly lyrical poetry was at least inspired by the mysticism of the Cathars. Religious poetry using erotic metaphors is very much a part of courtly rhetoric (de Rougemont, 102). Mystics of the 12th century had to express their love of the divine by using symbols that had a secret meaning (de Rougemont, 103). It is quite possible that we can interpret the words of the troubadours as a way of transmuting courtly love into a more precious 
essence, that of Eternal Love.

The Roman church had never favored the doctrine of love of the troubadours. It was under the order of Pierre de Castellnau, the papal legate of Innocent III, that the troubadour Gui d'Ussel stopped singing and writing around1208. Up to the Crusade against the Cathars the majority of the lords of the South didn't pay much heed to the criticism of the Church. Many of the lords even protected Catharism and often used their anti-Rome convictions to support their distain of ecclesiastic rights and confiscate the goods of the church abbeys. In this aristocratic and bourgeois society, René Nelli contends, where priests kept concubines and monks frequented powerful ladies of the courts, love seemed to have more loyal followers that did Rome (Nelli, 220). However, after the triumph of the Crusade and especially after 1233 , the date of the Inquisition, the situation changed. The Dominicans began to attack l'amour provençal and an already latent antagonism appeared between certain troubadours and the inquisitors who "condamnaient les pratiques de l'amour courtois, l'amour en dehors du mariage, comme les agents de la dissolution des moeurs grace à laquelle l'hérésie s'était propagée" (Coulet, 174).

The troubadours disdained the marriage bond which the Cathars called invati fornicatio (de Rougemont, 85). They hated the clergy and allies of the clergy, the members of the feudal caste. In fact, both the troubadours and the Cathars took a 
negative view of marriage, but for very different reasons. The troubadours saw marriage as a venal and "utilitarian" institution involving the subjugation of women- with few exceptions, true and equal marriage, they believed, could exist only outside of marriage. The Cathar Parfaits renounced marriage for themselves but tolerated it for the "believers" because although the sexual act, either within or outside of marriage, was "Satanic," there was always the possibility that it might lead to the reincarnation of a soul as part of the necessary progress toward perfection. To the extent that the Cathars tolerated marriage, they favored equality of the sexes, not the male dominance implicit in the Catholic dogma. The nobility in the South was sympathetic to the Cathars in this domain. The Catholic Church strongly opposed divorce yet, particularly among the nobility, divorce was not uncommon.The Cathars rejected marriage and so in another way, opposed the Church.

In their shared belief in the spiritual equality of men and women, however different the context, the Cathars and troubadours had certain ideas in common. In adition, they both attacked the greed and materialism of many of the clergy. To the troubadours this was an example of cobeitat, or covetousness; to the Cathars it was a sign of worldly corruption, the mark of Bélial (Marks, 247).

Although the troubadour system of love did not seek to meddle directly with any dogmas of the Church, it was at root heretical (de Rougemont, 224). There was an incompatibility with Christianity and courtly love. Andreas Cappellanus implies in his 
Art of Courtly Love that the troubadour ethic is based on nature, insisting that it is man's nature to love. Love also copies nature. What love forbids is contrary to Nature. The all encompassing importance and force of love in the attitude of the period can be seen in these words:

The rule of love shows us that neither woman nor man in the world can be considered happy or well-bred, nor can he do anything good unless love inspires him. (Cappellanus, 47)

Toward the end of the Middle Ages, individual and social life were laden with a religious atmosphere and concepts of faith. Many authors, according to Denis de Rougemont, call love an invention of the twelfth century because in fact courtly lyricism "invented" a more refined concept of love beween the two sexes. They affirm that a number of literary critics, following C.G. Jung, contend that "the chivalrous ideal compensated for the contemptous and repressive attitude of the clerical world towards woman" (Epiney-Burgard and Zum-Brunn, 178). Still others have devoted in depth attention to this "invention of the twelfth century" in trying to discover its source. Many theories lead to Arabic poetry, Christian idealism, or Cathar belief and mysticism. What seems prudent about the position of Epiney-Burgard and Zum-Brunn is their moderate appraisal that none of the theories has explained in a satisfactory way the origin and development of the idealization of the lady. The explanation lies, rather, in a complex interplay of historical, religious, artistic, and other cultural forces. 


\section{MYSTICISM}

Claude Marks explains that as early as the tenth century Hispano-Moresque poetry had a strong romantic quality, combining sensuousness and spirituality in a manner which anticipated the cult of courtly love in troubadour poetry. Not only is Arabic lyric poetry sensual, it has a sprititual content which is connected to the mystic Moslem movement of Sufism. This movement regarded love as a symbol of the soul's union with God, love being the primary cause of creation. Love could mean love of all creation but also the love of man and woman which was sublimated into an expression of personal union with the Divine. This idealization of love had a pre-Islamic origin, since Sufism, which emerged in the tenth century, borrowed ideas from neo-Platonism, Buddhism and Christianity. The Sufis had an exhaulted vision of women, which expressed itself in the belief that divine love could not be understood by anyone who had not experienced the transport of profane love- a concept not unlike that of the gai scavoir (joyous science) of the troubadours (Marks, 54).

These ideas are celebrated in a treatise on love by Ali ibn-Hazm of Cordova in which he entitles his chapters: "Of Love-Messages," Of Hints from the Eyes," and "Of the Submissiveness the Lover Owes his Lady" as well as other themes close to the fin' amor of the troubadours. The Platonic idea appears in his declaration that "the union of the spirit is more beautiful that the union of the body" (Marks, 55). 
"It is from you, Lady, that comes to me/ All the good that I say or do," writes the troubadour Aranaud de Mareuil. These lines express the essence of a personal relationship that lets the lover attain a higher psychic and moral level, and sometimes even divine love. "The art of just love" comes from courtly literature. The ideal proposed by the troubadours and other mystics is that of the noble soul, the proud soul who accepts all the trials imposed by God (under the form of Lady Love). In this transfer from the human experience to the divine realm lies the originality of some of the troubadours. But the feminist authors, Epiney-Burgard and Zum-Brunn contend that the primacy of love is expressed by some of the troubadours also in terms of the Metaphysics of Being(xxxi). They explored the encounter between Metaphysics of Love and Metaphysics of Being, already expressed by William of St Thierry. For them, as for him, "to love... is to be, and to be one single spirit with God" (Zun-Brunn, 23).

This is practically word for word the same philsosphy of love that the Cathars touted. I do not argue that the majority or even that some of the troubadours were professed Cathars, but rather that themes and allusions to Cathar philosophy may be seen in their works. The troubadours sing of an inaccessible love which demands of the lover an unreserved pledge governing his moral life (Zum-Brunn, 34). This corresponds closely to the Cathars' conception of love. However, Zum-Brunn contends that apparently it is not so much the woman loved as the song itself which keeps the poet's love, since the feeling expressed goes entirely into the poem. 
It is interesting to note that quite a number of ladies belonging to the Languedocian aristocracy dedicated themselves to the mystical life. Sephanie de Chateauverdun became a "perfected heretic" in 1245 , but she had a conventional marriage to avoid inquisitorial pursuit.

It is not coincidental that two out of three of the troubadours known to us ended their lives in monasteries, whether Catholic or Cathar (Zum-Brunn, 179). It seems more likely that troubadours would be protected by those sympathetic to Cathar beliefs since toward the end of the thirteenth century troubadours were exiled and ruined as were the Cathars. After them, in Southern France there was only silence. 
PART THREE:

POETS 


\section{PEIRE CARDENAL (1180-1276): HERESY AND POLITICS}

Peire Cardenal was probably born into a noble family at the end of the twelfth century. When it came to denouncing the errors and vices of his era, Peire Cardenal was very convincing (Nelli, Ecrivains anti-conformistes du Moyen Age, 269). He was at the court of Toulouse during the years just before the Crusade against the Cathars. He lived a long life-- almost a hundred years-- during which he knew two contradictory states in Europe: an Occitanian Europe where the themes of courtesia and poetry were honored and where the lands of Toulouse were free, and "French Europe" where the alliance of hypocritical clergy and military invasions caused the death of the "light of spirit" (perhaps his allusion to the exile and extermination of the Cathars). He was at the service of the count of Toulouse and he supported the cause of Raimon VII who was, according to René Nelli, a Cathar himself.

Peire Cardenal favored the genre of the sirventes, a poem of circumstance, essentially satirical and violent. The genre is specific to langue d'oc. His works treat political themes in which he speaks of hatred against the French. He is eloquent in his indignation toward the cruelty of Simon de Montfort, the French, and his disdain of the clergy. Some of his works are treatises on morality. Love for him is the perpetual search for perfection. In this chapter, I will examine the texts of his sirventes directed against 
the materialistic state of his era and specifically against the false clergy.

In his sirventes LVII he seems to renounce the world. The theme of simplicity and the return to simple ways is also central to the Cathar ideals. In other sirventes, Cardenal railed against the French invasion of Languedoc. In fact, Philippe le Hardi annexed Toulouse to the crown in 1271 and Cardenal wrote the poem "Totz lo mons es" in 1272. He expresses his animosity at the time of the Crusade itself with his sirventes XX, "Per fols tenc Polhes":

Per fols tenc Polhes e Lombartz - E Longobartz et Alamans, Si volon Frances ni Picardz -A senhors ni a drogomans.

(Translation) Je considère comme fous les gens des Pouilles et Les Lombards (Italie du Nord) et les Longobards (Italie du Sud) et les Allemands, s'ils veulent les Français et les Picards comme maîtres et truchements. (Compan, 129) According to André Compan, the changing of the régime took place relatively smoothly and not one troubadour was able to make a substantial protest. Compan contends that Peire Cardenal is a moralist much more than a political writer. In his poem LVII he complains about the dishonesty and injustice rampant among the clergy and the materialistic state of his era. He comments on the condition of the poor: "Il est peu aimé le pauvre, l'affligé, alors que trouve bénévolence le riche, l'homme aisé." Compan asserts that Cardenal displays definite Cathar or Manichaeist tendencies in this sirventes. At the same time, he does not disguise his hatred toward the French invasion of 
Languedoc. In Sirventes LVII, his passion and disdain for the loss of his homeland's identity are revealed:

Le jour où je fus né me fut decerné ce don: que m' agréa la manière d'agir des hommes bien élevés et que me fût pesante la malhonnêteté ainsi que les actes inconvenants.

Je vois tant d'hommes sots et tant d'autres fort retors, à tel point qu'aucun, en apparence, ne me semble équilibré, car à chevaux chargés, je trouve les dévergondés, qui sans aucune retenue réalisent leurs fourberies. L'un pille, pille, et l'autre prend, et l'autre encore est leur complice. Un autre est furieux, quand on se défend; l'autre vole et ment, et l'autre va tuer les gens pour de l'argent et l'autre pour rien.

Il y a assez d'abondance de vivres et de blés, mais il y a pénurie d'amour et d'actes d'honneur. Il aura suffisamment de martyre, s'il ne se corrige, celui qui pour de l'argent, trahit et devient un traitre, parce que c'est au feu ardent de l'enfer qu'il édifie sa situation.

Thus Peire Cardenal distinguishes himself by his passionate and eloquent sincerity, and by his hateful indignation against "tout ce qui viole le droit et la morale : les cruautés de Simon de Montfort et des Français, l'indignité du clergé, la corruption des moeurs, l'hypocrisie, la fraude, les femmes enfin, qu'il condamne avec amertume mais non sans esprit" (Bec, 303). His genius is particularly striking in two of his sirventes directed against the Jacobin preachers, the Dominican order of clergy who began the work of the Inquisition, and also in the "Sirventes à Dieu" where we can see 
that his ideas are not orthodox.

Peire Cardenal was a somber, serious, brooding aristocrat. No one really knows if he actually was a wealthy man, but he was sheltered in the courts of some of the richest men of his day. It was thanks to his influential patrons that he was saved from his powerful enemies. But many of his friends were defeated and the inquisition began to take hold in Languedoc. He, as other outspoken critics of the Church, had to leave his residence. It is generally believed that he spent the years from 1230 until his death in the late 1270's in Montpellier. Anthony Bonner sums up the tragic loss of a great artist to a "world gone mad": "Peire's exile from his native earth is all that one needs to prove the foreignness of the troubadours at the middle of the thirteenth century; by that time, they had become strangers in their own lands" (197).

It is reported that Peire Cardenal complained about everthing. He was not known for a gentle humor, but bitter laughter at best. But when one considers the age in which he was living, in which so many beautiful things were destroyed, music was silenced, and creativity was stifled, who can find fault with this poet?

René Lavaud published in 1957 his Poésies Complètes du Troubadour Peire Cardenal (1180-1278), a monumental work according to René Nelli, comprising all the works ever found by Cardenal. Lavaud includes the actual text in langue d'oc, translations, commentary, analysis of previous works, and a lexicon. Lavaud admits that the interpretation of the texts in Cardenal's works was arduous, and that a similar 
linguistic commentary on any troubadour did not not exist in France at that time.

Some of the sirventes or political commentaries or criticisms are specific to certain events or particular characters. But René Lavaud reminds us that trying to determine the true meanings of the troubadours' language is often ambiguous, mysterious, and difficult (Lavaud, 47). This often is referred to as tobar clus or closed hidden language. The message according to Lavaud is often obscure. Exact meaning regarding Cardenal's political or personal allusions are difficult to decipher. Lavaud suggests that although some certainties can be reached, we content ourselves with hypothesis. In that vein, I will attempt to illustrate the vague but probable allusions to Peire Cardenal's affiliation with Catharism. I will focus on his distaste for "the French" pitted against the Albigensians, and in particular his critique of the clergy as lascivious and dominators.

In the beginning of his career, he wrote more as a moralist. Lavaud says his strength lies in his sentence and argues that when the gnomic poetry of the troubadours is one day studied in its entirety, Peire Cardenal will be at the top in this particular genre. The term gnomic refers to thought, judgment, and intelligence. From this we have gnosis which is refered to as positive knowledge, recognition, and diagnosis in spiritual matters, such as was claimed to have been mystically acquired by the gnostics. And finally we look at gnostism: "a system of mystical, religious and philosophical doctrines, combining Christianity with Greek and Oriental philosophies propogated by 
early Christian sects that were denounced as heretical" (Lavaud, 34). Most of the troubadours are known for songs of love, Peire Cardenal was one of the few (together with Bertrand de Born and Guilhem Figueira) who wrote moral and political sirventes or satires, or gnomic works.

There are numerous sirventes in which Cardenal speaks out against the injustices of greed. That wealthy men use their power to usurp land, people, and riches, and submit the people to humiliation. He develops the theme that the rich barons of Gapencais get rich at the expense of people around them: "Le siècle est entièrement transformé en mal, car je vois que le riche mauvais et avare est honoré et le preux pauvre est avali par sa pauvrété."

Here I submit that Cardenal is castigating those in power who show no compassion for the poor. Further, the "preux pauvre" are most likely the Cathars striving to live a simple and honest life while being swallowed up by intolerant, more powerful forces.

The first two of the poems presented by Peire Cardenal must date from 1229 or 1230 . The "Sirventes à Dieu" is probably somewhat later since he mentions his children. It is not my intention to present each of the poems I study in the original Provençal; however, I will offer a passage here in the original Occitan language to illustrate the linguistic richness and interest of the originals. 
Occitan original excerpt:

\section{UN CLERGE INFAME}

Li clerc si fan pastor

E son aucizedor

E semblan de sanctor:

Quan los vey revestir,

E pren m'a sovenir

De n'Alengri qu'un dia

Volc ad un parc venir,

Mas pels cas que temia,

Pelh de mouton vestic,

$\mathrm{Ab}$ que los escarnic;

Pueys manget e trahic

Selhas que-1 abellic.

Rey et emperador

Duc, comte e comtor

E cavallier ab lor

Solon lo mon regir;

Ara vey possezir

A clercx la senhoria,

Ab tolre et ab trazir

Et ab ypocrizia,

Ab forsa et ab prezic;

E tenon s'a fastic

Qui tot non lor o gic

Et er fag, quan que tric.

Un Clergé infâme

Les clercs se donnnent pour bergers

Mais ce sont des assassins

Sous semblant de sainteté.

quand je les vois se vêtir,

Il me souvient de messire

Ysengrin voulant un jour

Entrer dans une bergerie :

Par crainte des chiens

Il endosse une peau de mouton

Pour tromper leur surveillance

Puis dévore par trahison

Les bêtes qui lui plaisent.

Ce sont les rois et les empereurs, 
Les ducs, les comptes et les "comtors,"

Joints aux chevaliers,

Qui gouvernent ordinairement le monde :

Maintenant je vois que les clercs

Se sont emparés du pouvoir

Et par l'hypocrisie,

Par la violence ou la prédication;

Ils sont forts dépités

$\mathrm{Si}$ on ne leur abandonne pas tout: il faut

Que leur volunté soit faite, en dépit de tout.

Puis ils sont grands,

Moins ils ont de valeur

Et plus de folie,

Et moins de franchise,

Et plus ils mentent

Et moins ils sont instruits,

Et plus il sont pécheurs

Et moins ils s'aiment entre eux.

C'est des mauvais clercs que je parle

Car je n'ai jamais entendu dire

Qu'il y ait eu pires ennemis de Dieu

Depuis des siècles anciens.

Quand ils sont au réfectoires,

Je ne trouve pas honorable

De voir les plus vils

Assis à la plus haute table,

Et être les premiers à choisir;

Ecoutez une grande vilenie[ :]

Ils osent y venir

Et on ne les écarte point.

Mais jamais je n'ai vu

Un pauvre diable de mendiant

S'asseoir à côté des riches;

Je vous assure qu'ils n'ont jamais commis pareille faute!

Que les Algais et les Almassors

Ne craignent pas

Que les abbés et les prieurs

Aillent envahir leurs terres

Et s'en emparer,

Car cela leur coûterait trop de peine;

Ici ils songent au moyen

De mettre la main sur le monde

Et de chasser messire Frédéric

De son abri.

Mais tel le défia 
Qui jamais ne s'en rejouit beaucoup.

Clercs, celui qui crut vous apercevoir Sans un coeur félon et injuste

A fait erreur de compte.

Car jamais n'ai vu gent pire que la vôtre.

English translation:

The clerics turn into shepherds,

Yet only to make the kill:

They radiate a saintliness

When they redon their garb;

They lead me to remember

How Lord Ysengrin* one day

Wanted to enter the sheepfold;

Yet because he feared the dogs,

He donned the fleece of a lamb,

And thereby had his jest:

How he butchered and devoured

Everything as he pleased!

The emperors and monarchs, Dukes, viscounts, and counts, Along with all their cavaliers, Are wont to rule the world. But now I see the possession Passing over to the priests, With snatching and betraying And plenty of hypocrisy, With foul play and preaching; And they treat you like a nuisance If you won't help play their game: You're done, as long as you delay.

The grander men they are, The fewer virtues shown, With more of foolishness And less of spoken truth More strongly bent on lying, With less companionship, More stronly urged to erring With less of priestliness. Of false clerks I say this: Mankind has not heard tell 
From the very oldest times

Worse enemies of God.

And when I'm in the refectory

I don't consider it grand,

For there at high table I see

The scoundrels all ensconced;

They're the first to dunk their bread.

Ah, listen to the infamy!

To think they'd enter there,

And nobody will toss them out!

And never yet have I seen

One of those poor begging scamps

Sitting next to his wealthy frère.

No! of that we can excuse them,

How they can drive out the Emperor,

Never need they have any fear,

Those conquering Arab Sayids,

For the abbots and the priors

Will never rush against them

Or try to seize their ground;

No, that would cause discomfort;

Instead, they direct their care

Toward how they can own the world,

Frederick, from his safe retreat.

Yet as soon as one attacks him,

He certainly shows no joy!

Clergymen, he who reads

Your hearts without guile and ill

Is making a baleful mistake,

For never did worse breed live.

In the second stanza Cardenal warns the people that if they don't play along with the powerful clergy, pretending with them that their power is to be issued in all matters, then they run the risk of being eliminated. In fact this came true, because the Cathars-or those suspected of sympathizing with Cathar thinking-- were eventually killed or driven out of France. 
Peire Cardenal is very clearly attacking the clergy for stealing, betraying the people, and above all for hypocritical behavior which was the antithesis of the pure faith. The Cathars were above all committed to taking care of the poor. Cardenal wishes to condemm the falsity of the clergy. He accuses them of murdering the people while pretending to nurture them: "Les clercs se donnent pour bergers; Mais ce sont des assassins." Here Cardenal clearly contends that the clergy pretends to attend to their pastoral duties of sheparding the flocks, while in reality they are part of the conspiracy to annihilate and do away with the new way of thinking and the new church in the south. They in fact are part of the treason against the Cathars led by the Vatican and carried out by the lords of the north as their warriors. Cardenal depicts the clergy as disguising themselves as sheep only to devour the flock as the aggressive wolf: "Il endosse une peau de mouton, Pour tromper leur surveillance, Puis dévore par trahison, Les bêtes qui lui plaisent." Cardenal further argues that it should be the kings, emperors, dukes, and even landowners who should govern the people. However, he sees the clergy, who "se sont emparés du pouvoir," abuse their power as spiritual leaders in every facet of temporal power by stealing and cheating the people and by acts of violence and taking advantage of less powerful parishoners. He complains that, unfortunately, their tenets will be enforced on this earth and the people will have no recourse. We are reminded of the Cathar doctrine that the clergy must not govern the people; "sacerdote non debent regere populum" (Nelli, 17). 
Although few scholars focus on the religious side of the war, the Crusade was effective in doing away with heresies (Marks,186). After the war the Church sent emissaries like Dominic, as models of strong but simple faith, to the South where the people would not tolerate luxury- loving priests. In addition, to combat the important secular love tradition in verse that had captured the imaginations of the southern French and had expanded into Germany, Spain, England, and Italy, the Church began to strongly support the spread of Mariolatry after having been critical of its growth for centuries. "Our Lady" seemed to be the acceptable way to give adulation and adoration to a woman. Women had grown too strong and powerful in the South for the taste of the Church in Rome. Now with Mary, the long suffering, the ideal of perfection, an idol which could only be striven for but of course never attained, the Church would add yet another restriction over the ebulliant and gender equitable South. It is for this reason that many later Provençal poems were written in hymn form, dedicated to the Virgin Mary called Leys d'Amor, works that were more remarkable for their rhetorical comments than for their lyrical quality (Marks, 188).

Peire Cardenal, a man of devout religious feelings, wrote what some consider the most famous hymn to Mary in the Provençal language. In this poem, particularly in the second stanza, it is my contention that the poet makes several allusions to the gnostic goddess Sophia, source of light and knowledge. Since the Church was discouraging the profane love poem, Mary, or some sacred image of goodness and purity replaced the 
likeness of the Lady at court:

1. Our true Virgin, our Maria,

Our true life and our true faith

Our very truth, our very way,

Our very virtue, creature true,

Our true mother, our true friend,

Our true love, our mercy true,

By the action of thy very grace

May thy heir inherit me!

If it please, Lady, lend us peace:

In thy son's name for me be it done!

2. Thou offer penance for the folly

By which Adam was taken over:

Thou art the star that points the way

To pilgrims in the Holy Land:

Thou art the dawning light of day:

Thy son is the resplendent sun

Who warms it and sends us light,

Truth-giver, of justice ever full.

If it please thee, Lady...

3. Thou wast born over in Syria

Noble but poor in worldly goods

Humble and pure and pious

In words and deeds and thoughts,

Created with such mastery,

Without an ill, with every good

Thou wast make so affable

Even God put Himself in thee.

If it please thee, Lady...

4. He who puts his trust in thee

Will never need another defense,

For though the world should perish,

Thou wouldst never pass away;

To thy prayers is humbled even

The Almighty -- displease whom it may--

Thy true will at any time

If it please thee, Lady...

5. David in prophetic measures

Sang in a psalm that he once wrote 
That on God's right hand was sitting---

The king promised in His written law-..

A mighty queen we might see wearing

Garments of orphrey and of vair:

Thou art she; there is no doubting

No dissenter can test the point.

If it please thee, Lady...

Many images used in the second stanza are symbols which were a part of Cathar belief. Cathar iconography in Southern France and elsewhere is extremely scarce, but what remains has been studied with a great deal of interest. Flying doves, symbol of the Holy Spirit and freedom of inspiration, fish, and a lamb's head have been discovered. The Cathars rejected the Roman or Latin cross, preferring a "discoidal cross" of which several examples have been found. It was essentially the Greek cross. The equality of the four branches is significant, as opposed to the Roman cross with its longer upright branch. Another Cathar image was the star with five rays, which some think may be an image of the human figure with outstretched arms and legs. Other esoteric symbols are believed to come from mystical Eastern sources or the Book of Revelation (Marks, 236).

In the second stanza, Cardenal writes: "Thou art the star that points the way." Clearly the Cathar star is the force in leading the way for the "pilgrims in the Holy Land." Many Cathars roamed the countryside in pairs preaching and doing good works.

The use of the themes of light and sun in the second stanza may be direct references to next line, Cardenal refers to her as the "truth-giver, of justice ever full." Truth was ultimately part of Cathar doctrine. Dishonesty was not tolerated. In addition, 
the Cathars renounced all violence. Homicide, war and secular justice were rejected along with all forms of lying or evasion of the truth (Marks, 237).

In the third stanza, the poet says that she came from the Orient as did the early Church, that she is "noble but poor in worldly goods, humble and pure and pious." These descriptions are at the core of Cathar thinking. In the fourth stanza, Cardenal reminds us that those who put their trust in her will never need another defense. Perhaps this is the defense needed against the Crusaders- a defense against the ultimate massacre of the Cathars by the forces of the political power in the North supported by the clergy in the South. Again Piere Cardenal did not appear to denounce his faith, but rather the temporal powers that clouded the true meaning of piety and goodness. Cardenal's reference to the world perishing lends insight into his long life which spanned almost a century. He witnessed with his own eyes the gradual decline of his native culture.

In the fourth stanza I believe Cardenal could be referring to the dissenter from the orthodox church, in fact the Cathars. Although this hymn is simple, there is a classic balance of traditional adoration of "Our Lady" with touches of symbolic references to another lady, one who had not been recognized by the Church of Rome.

Provençal literature started out with simple, emotionless hymns, and ended with sweet songs to mythical ladies and with forceful hymns to the Great Lady (Marks, 195).

It is ironic that the Church helped destroy the Provençal secular tradition, but while it waned, the Church received some excellent hymnal composition. The 
interaction between church and state can always be a topic of discussion while examining the poets of this era. Yet, as D.W. Robertson, Jr. says, this interaction should not suggest absolute polarity. Peire Cardenal attacked the Church as a political institution, but remained a Christian. This author, as well as others, finds the need to argue adamantly that he was not a Cathar or any other heretic. There does not appear to be enough proof either way. But for all his passion, devotion, and attention to criticizing the Church of Rome, his ideas were most certainly in line with those of Catharism.

The essence of the portrait of Peire Cardenal as a serious, brooding, aristocrat can be found in this telling account expressed by his biographer Michel de la Tour:

Peire Cardenal came from Velay, from the city of Puy Notre-Dame. He came from honorable stock, and was the son of a knight and a lady. And when he was small, his father put him in the principal cathedral school at Puy so that he could become a canon, and there he studied literature and learned how to read and to sing. And when he reached the age of a man, he fell in love with the vain things of this world and acted gay and handsome and youthful. And he invented many a beautiful song with a good message. He also wrote some love songs, but few. He composed many sirventes, and they were beautiful and fine. In those sirventes he showed a lot of good sense and good examples for those who will pay attention. For greatly did he castigate the folly of this world, and much did 
he reproach false clerics, as his sirventes prove.

Cardenal wrote more than a thousand sirventes directed toward the clergy and the encroaching "français" from the North, those who would do anything to retain power and control in the South.

After the war, various boards of inquiry were set up throughout the Toulousain that were the forerunners of the boards of the Inquisition set up by Pope Gregory IX. Peire Cardenal displays his outcry against this new kind of violence coming from Rome:

1. Not a buzzard, not a vulture

Can smell the stink of rotting flesh

Like those clerics and those preachers

On the sniff for earthly wealth.

Right away they're rich men's servants, And when they sense disease's swipe, Then they cozen out bequeathings:

The relatives have nothing left.

2. The Franks and the clergy get the praise For evil, since they're masters there; And the age about half For with their lying and their cheats They have so upset the world There's not a religious order left That hasn't mastered the lesson too.

3. Know what happens to all that loot

Belonging to those who get ill?

Up there swings a mighty robber: Nothing will he leave behind Name is death; O how he beats them! In just four ells of linen cloth Off he rolls them to his mansion Where they find other evil galore.

4. Man, why perpetrate such folly, Why transgress those commandments Of God, Who is your rightful Lord And formed our body out of nothing? 
He who battles against his Master

Would sell a good sow in the marketplace;

Yes, his earnings will be those

Won by that other villain, Judas.

5. Our true God, Who is full of sweetness,

Master, be our guarantor!

Keep us from the hellish tortures

Hold us sinners from torment safe;

Unravel those out of the evils

In which they're caught, in which bound:

Yield them for Your truthful pardon

In return for their true confessions.

In this work we can see all the aspects of complaint and resistance to the power of the French and the papacy. In the first stanza, Cardenal in effect gives the clergy animal-like characteristics such as those of a buzzard, or bird of prey, smelling out the opportunities for getting richer by tricking and using the people. He refers to the French and the clergy as "evil," thus condemning their vices in moral castigation. He criticizes the clergy for not setting better examples, and insults them for bathing in luxury while the poor go hungry. In the fifth stanza, the poet yearns for the simpler truer faith, imploring the "true God" to keep us from "hellish tortures." He asks that the perpetrators of evil be brought to justice, and in so doing confess their sins and thus be pardoned. Throughout this poem there are allusions to Cathar thought and influence. The stress on Good and Evil are strong indications of the dualism inherent in Manichaeism.

After the crusades against the Albigensians (about 1209 to 1244) the literature of love slowly disappeared and was replaced by a kind of pessimism. The troubadours 
tended to hide in libertinage, pure platonism, or religious mysticism. With the disappearance of the troubadours, an original form of poetry and civilization died forever (Nelli, Ecrivains anti-conformistes du Moven-Age Occitan, 13). 


\section{SELECTED TROUBADOURS}

\section{GUILHEM FIGUEIRA}

Guilhem Figueira, although originally from Toulouse, spent the majority of his life in Italy, where according to René Nelli, he was was a refuge, probably fleeing the threats of the Inquisition. He was the guest of Frederic II, who encouraged his nonconventional proclivities. Figueira proved himself to be an outspoken critic and adversary of French domination and of Rome. According to René Nelli, it is possible to presume that Guilhem Figueira was a heretic himself or that he had often frequented Cathar environments in Toulouse: "La présence dans ses poèmes d'expressions bien peu orthodoxes fait présumer qu'il était lui-même hérétique, ou qu'il avait beaucoup fréquenté les milieux cathares du comte de Toulouse" (Nelli, 243).

The works of Figueira consist of about ten pieces, all composed between 1215 and 1250. "Le Sirventes contre Rome," according to Jeanroy, is "la plus virulente satire que le moyen âge ait osée contre la papauté" (243). It is evident that he didn't hesitate to describe things as they were, in this time of massacres and man hunts, which could have cost him.

De faire un sirventes- sur cette melodie qui me convient, Je ne veux plus tarder- ni longtemps hésiter; 
Et ne doute pourtant qu'il me vaudra malveillances,

Car je fais ce sirventes

Sur les fourbes, les malappris

De Rome, qui est ---à la tête de la décadence

Ou tout bien déchoit.

Rome tricheuse, la cupidité vous égare:

A vos brebis---vous tondez trop la laine.

Que le Saint-Esprit--- qui revêtit un corps humain

Entende mes prières

Et brise tes crocs!

Rome, aux faibles d'esprit---vous rongez la chair et les os, Et vous guidez les aveugles ---avec vous vers la fosse;

Vous outrepassez les commandements---de Dieu, si grande

Est votre cupidité,

Car vous faites, contre denier

Remise des péchés.---Rome, vous vous chargez

D'un lourd fardeau de mal.

Rome, je sais en verite---sans nul doute--- que sous couleur De faux pardon, --- vous avez livre

Au martyre--- les barons de France,

Loin du paradis,

Rome, il est facile---de voir le mal qu'on doit dire de vous,

Car par dérision---des chrétiens vous faites des martyrs;

Mais dans quel livre---trouvez-vous que l'on doive

Rome, tuer les chrétiens?

Que Dieu qui est le pain véritable

Et quotidien---m'accorde de voir advenir des Romains

Ce que je désire...

Rome, si grande---est votre forfaiture

Que vous plongez dans l'oubli---Dieu et ses saints.

Et vous régnez si mal,---Rome fausse et perfide,

Qu'en vous cache

Se réduit et se détruit

La joie de ce monde.--Et vous faites grande démesure

A l'égard du compte Raimon.

Rome, pour de l'argent---vous faites maintes vilenies,

Maintes choses déplaisantes---et maintes félonies.

Vous voulez tant---régir le monde que vous ne redoutez rien:

Ni Dieu ni ses défenses;... 
Rome, que Celui qui est Lumière---du monde et vraie vie,

Et vrai salut vous donne mauvaise destinée,

Car tant sont vos méfaits, au su de tous,- que le monde crie.

Rome déloyale,

Racine de tous maux,

Dans les feux de l'enfer---ne manquerez de brûler,

Si ne changez vos pensées.

Rome, avec vos cardinaux, on a de quoi vous reprendre

Pour les mortels--- péchés dont ils font parler,

Car ils ne pensent qu'aux moyens---de revendre

Dieu et ses amis,

Et la réprimande pour eux reste vaine.

Rome, je suis irrité de voir grandir votre pouvoir

Et de voir grande peine--- nous accabler à cause de vous,

Car vous êtes abri et source--- de tromperie, de honte

Et de déshonneur.

Vos pasteurs

Sont hypocrites et fourbes,---Rome, et qui les fréquente

Fait bien grande folie.

Guilhem Figueira presents a style that is at once personal but virulent, and

makes violent attacks against the greed and treachery of Rome.

In the second stanza Figueira may reveal his Cathar tendencies. He refers to the

Holy Spirit as incarnate. In fact, it is not the Holy Spirit which is incarnate in the body of man, but rather Jesus Christ. In many Cathar texts, we find the idea that it is actually l'amour divin, and it alone, that is incarnate.

In the third stanza, the poet speaks of "remise des péchés." The "heretics" were known to reproach the Church for pardoning sins for money. This led later to the debate over "indulgences." 
In the following stanza, he contends that the barons (who were probably Cathars) were massacred for nothing, and that the pardon of sins accorded to the Crusaders was without value, since those expeditions were directed against good Christians (Nelli, 247).

In the fifth stanza Figueira is relentless in his disgust with Rome for having assumed to be so evangelical in ordering the systematic massacre of the inhabitants of a whole city (Béziers for example) under the pretext that the city was the core of heresy. Later in the verse the poet refers to a pure and clear Cathar principle: here Christ is not in the bread, He himself is the true spiritual bread.

Later, the poet's reference to "joy" may be viewed as joy from love and also spiritual Joy. I have tried to show that the Church viewed the doctrine of love of both the troubadours and the Cathars as equally heretical. His comments on Raimon VII, who was the last count of Toulouse, are sympathetic, in that Raimon was forced to marry his only daughter to the brother of Saint Louis, Alphonse de Poitiers. In addition, Raimon died in Milan exiled (or hidden) without being able to continue the fight against the French.

The poet's references to "true" are in direct collusion with Cathar theology: "Et vrai salut," "Lo vers salvaire," true as opposed to the false doctine of Rome.The reference to"Régir le monde" in the sixth stanza, is precisely that which prompts Cathar anti-clericalism in the well known quote: "quod sacerdotes non debent regere 
populum,"

"les prêtres ne doivent pas gouverner le peuple." 


\section{JAUFRE RUDEL}

I return to the argument that the idea of courtly love and fin' amor which the troubadours wrote about seems to have been inspired by the mysticism of the Cathars. It is particularly compelling when it is evident in much of lyrical poetry that passion was to be deflected in deference to a higher level of love. It is the very fact that the poets seek to transcend it that we may conclude that is religiously and mystically inspired.

The social atmosphere in Occitania, which I have proved to be in upheaval, produced a literary "religion" of chaste Love, cortezia, idealized women and their particular 'piety'; in sum a kind of pure joy d'amor.This literary "religion" contained detailed rites, which was the rhetoric of the troubadours. It included morals of hommage and service, as well as theology and theological disputes. It had its initiates and its "Believers." It provided original and fresh thought to a public who listened to them. Troubadour poetry became a religion ennobling love.

The troubadours seem to be able to reconcile the dilemma amid the turmoil of a divided society, not only between flesh and spirit, but also between heresy and orthodoxy, and in the heart of the Heresy, between the demands of the Parfaits and the actual life of the Believers. René Nelli interprets cortezia in the following words:

Nearly all the ladies of the Carcasses, of the Tolousain, of the Foix, and of the Albi region, were Believers, and were aware---although married---that marriage was 
condemned by their church. Many troubadours were undoubtedly Cathars, or at least were pretty fully aware of the current of ideas that had been in the area for two hundred years. In any case, they sang their lays for castles ladies, whose bad consciences had to be pacified by song, and who exacted from them less the illusion of a sincere love than a spiritual antipode to marriage, a state into which they had been forced (cited by de Rougemont, 114).

Nelli goes on to say that in his opinion "there can be no question of taking the chastity thus simulated as being either a real habit or a reflection of manners'; it had to be taken as a religious, (and so ceremonious) tribute rendered by imperfection to perfection--- that is to say, by the troubadours and by the Believers to the morality of the Perfect (Nelli, l'Erotique des Troubadours, 198).

I believe that the concept of distant love or amor de lonh is an expression of an attempt to transcend love in a mystical way. The poet tries to define love as the ultimate good or aim in life and to disover how the human being orientates himself towards it. The love of the distant land or the distant lady is not a reflection of objective reality, but is a concrete expression of a universal principle or the innate inclination of nature in the search for happy life; a metaphysical concept of love as an immanent and vital activity deriving from the intuition of one's own self (being) as good and pure, and striving towards the absolute truth and goodness to which one feels to be bound. In this interpretation the lady is a form of one's own self (Lindsey, 70.) 
Jaufré Rudel displays many examples of the inaccessible lady, considered as an abstract principle of beauty, love, and aspiration. His themes revolve around working out the results of utter devotion to love, a cause, an ideal of self-fulfillment.

He wrote six poems all of which are about love. Two poems deal with a love in a distant land, and another seems to celebrate a woman who seems to be like a spirit. The following two poems appear to be real, but Rudel explains how he is lost between dream and reality:

This love absorbs me every bit, waking and seeing them in dreaming sleep. I feel such joy, enjoying it, rejoiced in and rejoicing deep. No profit from her charms I keep, for no friend has revealed to me how pleasure from them I might gain.

So eagerly to her I ride in haste to bring about our meeting, still backwards I appear to slide and she is steadily retreating.

So slow my horse, my heart stops beating. Unless she halts and waits for me I'll never reach her, I complain.

Rudel makes allusions to the impossible union that he is eager to reach. He most likely is refering to perfection or unfulfilled longing to be surrounded by love. He seems to slide backwards and the goal retreats. In other words, he makes efforts to improve, to strive towards goodness, but human nature takes over and he concedes he will never reach parfecpioem referred to as "phantom," since the poet has never seen the beloved he writes:

No wonder if my love should be 
for one who has never seen my face.

My joy depends upon her grace, though I've not seen her. Joy for me lies all in her, yet I can't say what good in it I'll ever trace

He develops the paradoxical themes of loss and possesion. He falls in love and then dies of joy; the sting of love makes him burn; his whole body perishes; never has he felt such a blow followed by such languor. His dreams are nightmares. But when he awakes, his torment is gone. These descriptions are not unlike those of the experiences of the mystics. They often told of physical sensations of burning, ascending, sinking, that seemed not to have any tangible visible explanations.

Scholars do not know a great deal about this poet although he was a noble man from Blaye. In the vidas or biographies they say he fell in love with the Countess of Tripoli, whom he had never seen. He traveled to meet her, but became ill on the trip. The Countess came to his bedside where he died in her arms. He was buried in the House of the Templars.

This account is only a legend, but it fit in well with the songs of the Distant Lady:

Love of a country far away has filled my flesh with suffering. Nothing can save me but a sign from her: to say that she'll allow embraces warm in alcove-play or under the cool orchard-line Since for her company I long.

As never luck of love is mine, 
I burn, and none need ask me how.

God made all other women clay

Christian or Jewess withering,

or Moor. My girl is beauty's shrine.

For manna he won't need to pray,

the man to whom her smiles belong.

The reference to suffering flesh is a direct sign of the poet's attempt at chastity.

The Cathars in particular regarded the body as that "eminating from darkness." Later he comments on 'manna' for which he won't need to pray. It is possible that he is referring to Mani the god of Manichean thought in early East Indian mysticism, which is at the root of Cathar philosophy.

In the words of Anthony Bonner, Rudel takes platonic, unrequited love to its logical conclusion--- where love itself becomes the aim, the thing desired, because fulfillment would destroy it or lessen its intensity. In addition, he sings of his "distant love" in a language that is simple and direct (paubres motz as his biographer put it), yet full of veiled, obscure allusions. He moved in a world close to that of mystics, where the sensual and the divine become fused (Bonner, 62). Nobody can say for sure, but Jaufré Rudel, according to Bonner, was like no other troubadour. One thing is sure, this poet seems to move easily between the earthly and the divine, or exist somewhere in between.

In the following poem, the Distant Lady again is symbolic of the quest for purity, joy, goodness, and love.

When now the days are long in May, I love to hear the birds far distant, 
and when the song has died away, I dream about a love as distant. Deep in my longing am I drowned. The songs, the hawthorne-bloom around, warm me no more than winter snow.

But I believe the Lord one day will let me see this love that's distant. As for one good, my lot, l pay with double ills, since it's so distant. Would as a pilgrim I were gowned, with cloak and staff to tap the ground, I'd draw her eyes to note my woe.

Love has no joy that won't betray except this love that lies so distant. Such charms no woman can display in any land that's near or distant.

My accuser cries, as well he may, I'm broken by a love far distant. With one desire on earth I stray; it's to enjoy that love so distant. But my desire's denied and banned; loving, unloved, I bear the brand-to my godfather this lot I owe. With my desire denied and banned, loving, unloved, I curse the brand and him to whom this lot I owe.

In the second stanza, the poet refers to himself as a pilgrim. I believe it is possile that he is making allusions to the Cathar Parfaits who roamed the country side with their simple clothing and walking sticks.

In the third stanza Rudel's reference to his accuser may be the forces which disallow him to express his faith in God the way he chooses.

We could say that the Distant Lady is every woman truly loved and loving, and the symbol of distance refers to the element of the unknowable in her-- in every person including the poet himself. Here like the Cathars was a strong conviction that the 
movement of Love is towards knowledge of the other and of oneself. But with each step toward new conscious levels there is at the same time opposition and union; new ways of looking at closeness and distance become apparent. 


\section{DAME CARENZA, ALAIS ET ISELDA -.- Liberated Trobairitz}

Three women about whom very little is known wrote a poem that most scholars find very curious. I add this piece since it contains a unique and ambiguous feature about the spirituality of Alaiis and Iselda.

These two young women of the world, "bien enseignées" and gifted with all the qualities appropriate to noble women (beauty, youth, merit) ask each other if they should marry or enter the convent. They consult Dame Carenza, who is apparently a woman of experience.

Alaiis and Iselda were sisters and even though they speak through only one voice in this poem it represents two women. According to René Nelli, they were devoted to mysticism and a life of "continence" (abstinence), but it is especially clear they are critical of the ugly effect of pregnancy (Nelli, Ecrivains anti-conformistes, 25). They are adviced to marry the "Coronat de scienza." Meg Bogin, author of The Women Troubadours, contends that this a likely allusion to a Cathar (or Gnostic) name for Christ (Bogin, 145). The sisters will thus have a husband but no children. As the poem expresses a clear disgust for procreation, disgust that seems to have been shared by many beautiful "châtelaines" of the thirteenth century (if in theory only), it is reasonable to conclude that it reflects a certain Cathar thought. Rene Nelli expresses his hunch in explaining that even the way things are expressed doesn't appear very Catholic (Nelli, 
257). But it is a religious institution (many of which were Cathar) that the two sisters are considering entering. Dame Carenza, asks them to pray for her once they are there.

Lady Carenza of the lovely, gracious body, give some advice to two sisters, and since you know best how to tell what's best, counsel me according to your own experience: shall I stay unwed? that would please me, for making babies doesn't seem too good, and it's too anguishing to be a wife.

Lady Carenza, I'd like to have a husband but making babies is a huge penitence: your breasts hang way down and it's too anguishing to be a wife.

Lady Alais and Lady Iselda, you have learning, merit, beauty, youth, fresh color, courtly manners and distinction more than all the other women that I know; I therefore advise you if you want to plant good seed, to take as a husband Coronat de Scienza, for whom you shall bear glorious sons: saved is the chastity of she who marries him.

The works of the women troubadours is not widely known. There were twenty acknowledged trobairitz, as they were called in Provençal. Although they wrote about love, Meg Bogin tells us that the womens' language and situations are remarkably different from those of the men troubadours. The women prefer the straight forward speech of conversation. She suggests that perhaps this is because the women, unlike the men, do not idealize the relationships they write about. The women do not worship men, nor do they seem to want to be adored themselves (Bogin, 13). 


\section{CONCLUSION}

The Cathar movement, a desparate search for a simpler, more pure, and authentic alternative to an expression of faith in God, itself gradually withered away. The Southern French, exhausted by war, contention, and constant scrutiny by the clergy, were anxious to negotiate any conditions for peace. The south was devastated and the drain on resources, the undoing of local power, the brutal treatment of Cathars, the cruel combat of brother against brother and relative against relative, left a heritage of resentment that has not totally died out in southern France, even in the present day.

In 1250 Catharism had vanished, but the Church had found the other form of heresy to contend with, that of Love. It was essentially a common cause for the Church. Amors became an object of scandal. Those who tried to defend Love, insisting on the virtues it developped, only succeeded in underlining its heretical character. The troubadours insisted that the instinct of love allowed good inspirations to be born in the soul, and that even according to some, the love signified something more obscure, that love of the lady was "cause" and love of God, consequence; or if one prefers, that love is the origin of all virtues (Nelli, l'Erotique des Troubadours, 136).

I cannot conclude that the selected troubadours were in fact themselves Cathars. But they were at least Cathar sympathizers. It is clear that borrowings from Cathar thought and philosophy appear in many of the works. Furthermore, they seem to be so 
thoroughly engaged in a rebellious anti-conformist direction that they certainly may be referred to as dissident Christians. The troubadours appear to have voiced their hostility, either vehemently or insidiously (trobar clar ou trobar clus), against the forces that were overturning their world.

At the time of the troubadours, Occitanian society was remarkable for its diversity as well as its unique traits. It was open to exchange with those of other cultures and faiths. Women did face, just as everywhere else, misogyny, exclusion, and coercion; but in Occitanian society, women had more power and influence, a voice, and certain social freedoms not accepted in other parts of Europe. It was more a courtly society rather than a chivalrous one; there was less division between classes. The mercantile economy was expanding which allowed for social mobility. All this, together with an atmosphere of religious tolerance among its indigenous people, suggests that this culture was not in need of reform. The most significant problem, the break between the clergy and the laity, seems to have come from the inept intrusions of the Inquisition and the French Monarchy. Occitania was not paradise. But it had many qualities of a healthy, vibrant, diverse, creative culture. Ironically it was the first casualty of a persecuting society, the victim of a desire on the part of outsiders to dominate and control.

Peire Cardenal brilliantly expressed his feelings of outrage against the greed and usury of a hypocritcal clergy. In his works, which were mostly sirventes, he railed 
against the abuses, injustices, and corruption that permeated the South.

Guilhem Figueira was a violent voice, unique in his piercing and unrelenting criticism of Rome, its clergy, and the accompanying destructive French forces in Occitania. His indignation against the Church, his protestation of the massacre of the inhabitants of Béziers in 1209, do not necessarily imply that he was a Cathar. But we know that he was at least a sympathizer, since he defended their causes.

Jaufré Rudel reminds us of an intangible love, a quest for the ideal. His expressions of love represent a kind of tormented joy. He aspires to perfection and pure love not unlike the Cathars.

Three women troubadours, Dame Carenza, Alaïs and Iselda, wrote a curious poem which provides insight into their ambiguous spirituality that leads us to believe that they were at least somewhat influenced by gnostic thought and belief. Their work sheds light on the feminine experience of the time. In addition, althought they wrote about love, it is clear that the language and the situations they describe are strikingly different from those of their male counterparts.

It is unfortunate for the literary world that no written works from the Cathars were preserved. The Cathars were all massacred, burned, or repressed. Only the deserted remains of once vibrant communities barely stand. The Cathars or the Church of Love is a story of cursed love, of unattainable love, of love tied to another story of love- that of the troubadours. Their connection speaks to us today not only about love, 
but about questions of equality, tolerance, and personal liberty. 


\section{WORKS CONSULTED}

Anraud, Paul Henri Auguste. La Vie et L'Oeuvre du Troubadour Raimon de Miraval.

Bec, Pierre. Anthologie des Troubadours. Paris: Union Generale d'Editions, 1979.

Bellperron, P. La Joie d'amour; contribution à l'étude des troubadours et de l'amour courtois. Paris: Plon, 1948.

Betsky, Aaron. Building Sex: Men, Women, Architecture and the Construction of Sexuality. New York: William Morrow and Company, Inc., 1995.

Briffault, Robert. The Troubadours. Bloomington, Indiana: Indiana University Press, 1965.

Bezzola, R.R.. Les Origines et la formation de la littérature courtoise en Occident (5001200). Paris: Champion, 1967.

Bogin, Meg. The Women Troubadours. New York, London: W.W. Norton and Company, 1980.

Bonner, Anthony. Songs of the Troubadours. New York: Schocken Books, 1972.

Camproux, Charles. Le Joy d'Amor des Troubadours. Montpellier: Causse et Castelnau, 1965.

Cazelles, Brigitte. The Lady as Saint: A collection of Hagiographic Romances of the Thirteenth Century. Pittsburgh: University of Pennsylvania Press, 1991.

Cropp, G.M. Le Vocabulaire courtois des troubadours de l'époque classique. Geneve: Droz, 1975.

De Rougemont, Denis. Love in the Western World.Princeton, N.J.: Princeton University Press, 1983.

Denomy, A.J. "Fin' Amors, the Pure Love of the Troubadours; Its Amorality and its Possible Source." Medieval Studies. Vol.7, (1945): 139-207.

Dronke, Peter. Women Writers of the Middle Ages. Oxford: Cambridge University Press, 1984. 
Medieval Latin and the Rise of European Love-Lyric. Oxford: Clarendon Press, 1968.

Epiney-Burgard, Georgette, and Emilie Zum-Brunn. Women Mystics in Medieval Europe. New York: Paragon House, 1989.

Erbstosser, Martin. Heretics in the Middle Ages. Leipzig: Edition Leipzig, 1984.

Field, W. H. Raimon Vidal: Poetry and Prose. Chapel Hill: University of North Carolina Press, 1971.

Furlong, Monica. Visions and Longings; Medieval Women Mystics. Boston: Shambhala, 1996.

Gaunt, Simon. Troubadours and Irony. New York: Cambridge University Press, 1989.

Golden, Frederick. Lyrics of the Troubadours and Trouvères. New York: Doubleday Anchor Books, 1963.

Guiraud, J. Histoire de l'Inquisition au moyen age. Paris: Payot, 1938.

Hamlin, Frank B. Introduction à l'étude de l'ancien provençal. Geneva: Droz, 1967.

Jeanroy, Alfred. Anthologie des Troubadours XIIme - XIIIme Siècles. Paris: Librairie A.G. Nizet, 1974.

....... Bibliographie Sommaire des Chansonniers provençaux. Paris:Champion, 1916.

....... Histoire Sommaire de La Pósie Occitane: des Origines à la fin du XVIII siècle. Paris: Privat-Dédier, 1945.

Les Origines de la Poésie lyrique en France au Moyen Age, 4e ed., Paris, Champion, 1969.

Harksen, Sybille. La Femme au Moyen Age. Leipzig: Edition Leipzig, 1974.

Hill, R.T. Anthologie of the Provençal Troubadours. Yale University Press: 1973.

Julien, Lucienne. "Influence du Catharisme sur la littérature de son époque." Cahiers d'Etudes Cathares. Vol. 34, no. 97, (1983).

Lambert, Malcolm. Medieval Heresy: Popular Movements from Bogomil to Hus. London and New York, 1977. 
Lavand, René. Poésies Complètes du Troubadour Peire Cardenal (1180-1278).

Toulouse: Bibliothèque Méridionale, 1957.

Lazar, M. Amour Courtois et Fin'Amors. Paris: Klincksieck, 1964.

Lindsay, Jack. The Troubadours and their World. London: Frederick Muller Limited, 1976.

Lot-Borodine, Myrrha. De l'Amour Profane à l'Amour Sacré; Etudes de psychologie sentimentale au Moyen Age. Paris: Librairie Nizet, 1979.

Madaule, Jacques. The Albigensian Crusade. Trans.Barbara Wall. London: Barns and Oates, 1967.

Marks, Claude. Pilgrims, Heretics, and Lovers. New York: Macmillan, 1975.

Marrou, Henri-Irenée. Les Troubadours. Paris: Editions Seuil, 1971.

Marteil, Jean-Louis. Et Dieu Reconnaîtra les Siens. Portet-sur-Garonne: Editions Loubatières, 1994.

Nelli, René. L'Erotique des Troubadours. Paris: Privat, 1964 .

La Philosophie du Catharisme: Le Dualisme radical au XIII siècle. Paris: Editions Payot, 1975.

Les Cathares en l'eternel combat: culture, arts, loisirs. Paris: Grasset, 1972.

Les Cathares. Collab. Avec F. Niel, D. Roche, J. Duvernoy. Paris: Editions de Delphes, 1965.

...... Martirs del Pur Amor Crestian. Paris: Payot, 1967.

...... Les Ecrivains anti-conformistes du Moyen Age Occitain. Paris: Editions de Delphes, 1976.

N..... Le Phenomène cathare. Toulouse: Privat-P.U.F., 1968.

...... La Vie Quotidienne des Cathares du XIII siècle au Languedoc. Paris: Hachette, 1969.

Niel, Fernard. Albigeois et Cathares. Presses Universitaires de France, 1955.

Oldenbourg, Zoë. Massacre à Montségur. Trans Peter Green. London: Weidenfeld and Nicholson, 1961.

....... Cities of the Flesh.

Patterson, Linda.The World of the Troubadours; Medieval Occitan society, c. 1100-c. 1300. Cambridge: University Press, 1993. 
Picot, Guillaume. La Poésie Lyrique au Moyen Age. Paris: Libraire Larousse, 1975.

Parry, John Jay, ed and trans. The Art of Courtly Love of Andreas Capellanus. New York, 1964.

Topsfield, L.T. Troubadours and Love. Cambridge: Cambridge University Press, 1975 .

Wakefield, Walter L. Heresy, Crusade, and Inquisition in Southern France, 11001250. Berkeley, 1974.

Wilhelm, James, T. Seven Troubadours; the creators of modern verse. University Park: Pennslvania State University Press, 1970.

Wolf, George and Roy Rosenstein. The Poetry of Cercamon and Jaufré Rudel. New York and London: Garland Publishing, Inc, 1983. 